\title{
The Fictional Representation of Modern Urban Concentration in the Work of J.G. Ballard
}

\author{
By Zeynep Tuna Ultav*
}

The main aim of the study is to describe new approaches to the understanding of the consequences of modernism, which will be constructed through a unique reading of fictional media with regard to architectural discourse. In this respect, the work of J.G. Ballard, a British New Wave writer, has been selected as a fruitful dystopian source. The urban concentration, a distinguishing principle of modern architecture, is one of the prevailing themes in the construction of Ballard's New Wave novel. The scope of this study is to analyze three science fiction stories by J.G.Ballard in order to convey this modernist urban principle. The Concentration City (1957) displays the dystopia of an over-populated city in which there is an absence of open space. Chronopolis (1962) displays the dystopia, in which city dwellers' use of the city is restricted through legal procedure. Billenium (1961) is another Ballardian story which conveys the restriction on living space to cells of $3 \mathrm{~m} 2$, imposed by the 'Residential Committee' when the population exceeds 20 million. In conclusion, the study has the potential to contribute to the discussion on the theme of modern urban concentration within a modernist critique. Thus, reading Ballard's work helps to develop an original perspective revealing his over-exaggerated view of urban concentration.

\section{Introduction}

The main aim of the study is to describe new approaches to the understanding of consequences of the modernism, which will be constructed through a unique reading of fictional media with regard to architectural discourse. In this respect, the work of J.G. Ballard, a British New Wave writer, has been selected as a fruitful dystopian source.

Literature can be put forward as a textual repertoire, which is able to enhance the relationship between collective memory and spaces, creating new practices of understanding penetrating into the layers of meaning of spaces. The views of writers offer us other points of view, charged with different perceptions (Tümer, 1997; Thompson, 321).

*Assistant Professor, Izmir University of Economics, Department of Interior Architecture and Environmental Design, Turkey. 
Science fiction literature, as opposed mainstream literature, is considered to present a more affluent literary space. For example, James describes the intensity of the structure of science fiction compared to the mainstream, and contrasts their purposes; mainstream fiction expresses perceptions about the human psyche within the world of our own experience as its setting, whereas science fiction speculates about the potentialities and possibilities of human species and its place in the universe and changing the world of our experience (James, 1994:96). The reason for considering Ballard's fiction as a case study arises from the fact that such literature provides an effective criticism on the modern landscape, and particularly on the modern urban concentration. While it is also possible to explore the definitions related to physical environment through other science fiction work, Ballard's literature specifically takes the definition of the physical environment as the fundamental factor in the definition of the social environment. According to Jonathon S. Taylor, the characters are described as alienated bodies reacting against the new modern situation (Taylor, 2002), as seen in the following observation 'the protagonists find themselves in situations where their subjectivity is altered by changes in the built environment' (Taylor, 2002:95).

The urban concentration, which is a distinguishing principle of modern architecture, is one of the prevailing themes used by Ballard to construct some of his New Wave novels. The scope of this study is to analyze three stories by J.G.Ballard in order to shed light on this modernist urban principle. The Concentration City (1957) displays the dystopia of an over-populated city in which there is no open space. Chronopolis (1962) displays the dystopia created by legal restrictions on the use of the city by the dwellers. The name of the city, Chronopolis, is ironic, because all mention of time is forbidden. Billenium (1961) is another Ballardian story which conveys the restriction of the living cell to $3 \mathrm{~m}^{2}$, imposed by the 'Residential Committee' of the city when the city population reaches 20 million.

\section{Modern Urban Concentration in Ballard's Work}

The density of the city and the transformation by scale affect each other. Density can be understood in two different ways; firstly, the number of people in a city contains in relation to other cities, and secondly, the consequent number of multifloor apartment blocks. Clearly, the second depends on the first. In addition, it is possible to say that multi-floor buildings, which make the city look denser due to their height, both create and result from density.

The theme of density of the city is described in Ballard's discourse, first, in The Concentration City, in terms of a dystopia of a very dense and enclosed area. ${ }^{1}$ Gasiorek puts forward the city, which 'posits an infinitely extended metropolis' as 'subject to economic laws urban development and the price of mechanism' (Gasiorek, 2005:102). The title of the story gives some idea about the concept of density as well. The main character, Franz, a physics student,

\footnotetext{
${ }^{1}$ The earlier name of the story is Build Up.
} 
believes that there is a wall surrounding the city, and that beyond the wall is a 'free area'; in other words, an open city area with no buildings. Others try to convince Franz that this is not true, and that the eternity of the city is parallel to the eternity of time, without beginning or end. Even if he traveled a lot, he would end up at the same location:

'The surgeon nodded to himself. "Some advanced opinion maintains that there's a wall around the City, through which it's impossible to penetrate. I don't pretend to understand the theory myself. It's far too abstract and sophisticated. Anyway I suspect they've confused this Wall with the bricked-up black areas you passed through on the Sleeper. I prefer the accepted view that the City stretches out in all directions without limits" (Ballard, 1971:230).

Franz (M.) believes that the city has boundaries and that there is free space behind those boundaries. He, like other residents of the city, is persuaded by the statement that the spatial character of the city reflects the concept of time:

'The surgeon hesitated before opening the door. "Look," he began to explain sympathetically, "you can't get out of time, can you? Subjectively, it's a plastic dimension, but whatever you do to yourself you'll never be able to stop that clock", he pointed to the one on the desk "or make it run backward. In exactly the same way; you can't get out of the City."

"The analogy doesn't hold," M. said. He gestured at the walls around them and the lights in the street outside. "All this was built by us. The question nobody can answer is: what was here before we built it?"

"It's always been here," the surgeon said. "Not these particular bricks and girders, but others before them. You accept that time has no beginning and no end. The City is as old as time and continuous with it."

"The first bricks were laid by someone," M. insisted. "There was the Foundation."

"A myth. Only the scientists believe in that, and even they don't try to make too much of it. Most of them privately admit that the Foundation Stone is nothing more than a superstition. We pay it lip service out of convenience, and because it gives us a sense of tradition. Obviously there can't have been a first brick. If there was, how can you explain who laid it, and even more difficult, where they came from?"' (Ballard, 1971:229)

Regarding the density of the city, the most effective criticism against the density resulting from the people living in the city can be seen Ballard's Chronopolis dystopia. In the story, it takes two or three hours to travel to work or they spend a long time in meal queues. To solve this problem of excessive 
wait times, restrictions were imposed. For example, times for starting work were staggered according to areas. Ballard describes this restriction as follows:

"Fifty years ago, when the population was only ten million, they could just provide for a potential peak capacity, but even then a strike in one essential service paralyzed most of the others; it took workers two or three hours to reach their offices, as long again to queue for lunch and get home. As the population climbed the first serious attempts were made to stagger hours; workers in certain areas started the day an hour earlier or later than those in others. Their railway passes and car number plates were colored accordingly, and if they tried to travel outside the permitted periods they were turned back. Soon the practice spread; you could only switch on your washing machine at a given hour, post a letter or take a bath at a specific period"' (Ballard, 1962b:129). follows:

The cause of this restriction is explained through urban density, as

'Think of the problems, though. Transporting fifteen million office workers to and from the center every day; routing in an endless stream of cars, buses, trains, helicopters; linking every office, almost every desk, with a videophone, every apartment with television, radio, power, water; feeding and entertaining this enormous number of people; guarding them with ancillary services, police, fire squads, medical units - it all hinged on one factor' (Ballard, 1962b:127-8).

They enforced the system in Chronopolis through a system of color coding. Thus, the users of the city had colored passes, colored money, and an elaborate set of daily schedules transmitted through TV or radio programs to organize the coding system. Also, they employed thousands of clocks within the city. The secondary officers announced the number of minutes remaining in any activity period, according to the clock's color category. The main character in Chronopolis, Conrad, has come to the city for the first time and is attempting to adjust to it. He defines the people lived in this city as "'giants' (Ballard, 1962b:127). This is an objective assessment of the crushing effect of buildings on people. In this respect, in addition to the organization of time in Chronopolis, which provide limited solutions to the density of the city, it is possible to see the density of the apartment blocks resulting from overpopulation. In addition, the overpopulation problem is solved by building multi-floor buildings. Ballard expresses the hegemony of the multi-floor buildings by talking about the affinities of the cities with the "long glass abysses looking as if they were carrying the sky" and with 'forest'. He also remarks that buildings leave no room for anything else in the city: 
'They left the expressway and swung off down a ramp that fed them into the northeast corner of a wide open plaza, eight hundred yards long and half as wide, down the center of which had once been laid a continuous strip of lawn, now rank and overgrown. The plaza was empty, a sudden block of free space bounded by tall glass-faced cliffs that seemed to carry the sky.

Stacey parked, and he and Conrad climbed out and stretched themselves. Together they strolled across the wide pavement toward the strip of waist-high vegetation. Looking down the vistas receding from the plaza Conrad grasped fully for the first time the vast perspectives of the city, the massive geometric jungle of buildings' (Ballard, 1962b:127-8).

The clocks that organized urban life described are by Ballard as 'fantastically complex social organism' (Ballard, 1962b:127), though were very dominant within the city:

'Stacey put one foot up on the balustrade running around the lawn bed, pointed to the far end of the plaza, where Conrad saw a lowlying huddle of buildings of unusual architectural style, nineteenth century perpendicular stained by the atmosphere and badly holed by a number of explosions. Again, however, his attention was held by the clock face built into a tall concrete tower just behind the older buildings. This was the largest clock dial he had ever seen, at least a hundred feet across, huge black hands halted at a minute past twelve. The dial was white, the first they had seen, but on wide semicircular shoulders built below the main face were a dozen smaller faces, no more than twenty feet in diameter, running the full spectrum of colors. Each had five hands, the inferior three halted at random' (Ballard, 1962b:128).

Conrad, the protagonist of the story, is taken to the suburbs, which have been abandoned in the metropolis, increased in density, and led to the need to abolish time. The phenomenon of suburbs sometimes gives information about the existence of the suburbs only as in Ballard's multi-floor buildings. Ballard defines the hegemony of the suburbs in Chronopolis. Sanna calls Chronopolis 'a non-place, while the new Chronopolis has been deprived of time, thus being characterized by non-time' (Sanna, 2013):

'One suburban center gave way to another, to long intervening stretches of congested ribbon developments. Mile by mile, the architecture altered its character; buildings were larger, ten or fifteen-story blocks, clad in facing materials of green and blue tiles, glass or copper sheathing. They were moving forward in time rather than, as Conrad had expected, back into the past of a fossil city' (Ballard, 1962b:126). 
In Chronopolis, the suburban settlement are tightly-packed, and the abandoned areas between them consist of concrete gardens, sloping centers and car park slopes which are not considered part of the publicity of the city. Apartment blocks are compared to 'giant dominoes':

'In a few minutes they passed between the first of the apartment batteries, the thousands of identical living units with their slanting balconies shearing up into the sky, the glass in-falls of the aluminum curtain walling speckling in the sunlight. The smaller houses and shops of the outer suburbs had vanished. There was no room on the ground level. In the narrow intervals between the blocks there were small concrete gardens, shopping complexes, ramps banking down into huge underground car parks' (Ballard, 1962b:126)... Conrad craned forward. In the distance, two or three miles away, the rectilinear outlines of enormous apartment blocks reared thirty or forty stories high, hundreds of them lined shoulder to shoulder in apparently endless ranks, like giant dominoes' (Ballard, 1962b:126).

The phenomenon of the density of the city can also be clearly seen in Billennium story (1961) in which the 'Dwelling Committee' decreases the legal living area from 4 to 3 square meters when the population reaches 20 billion. Twenty five years ago, people opposed the cut in the square meters saying that they cannot even open the door, but then in order to counter this rejection, it was decided that from then on all doors would open outwards. In Billennium, the architectural equivalent of the density is the minimum size of the living units:

'...The cubicle was slightly more than four and a half square meters in floor area, half a square over the statutory maximum for a single person, the carpenters having taken advantage, illegally, of a recess beside a nearby chimney breast. Consequently, Ward had been able to fit a small straight-backed chair into the interval between the bed and the door, so that only one person at a time need sit on the bedin most single cubicles, host and guest had to sit side by side on the bed, conversing over their shoulders and changing places periodically to avoid neck strain' (Ballard, 1962a:8).

Since the units of living do not meet the life needs, people try to find solutions by the effective use of the space in their apartments. In a unit of 4 square meters, half square meter is vital. The friends of John, one of the main characters in the story, are jealous of his extra space. Ballard emphasizes the difference between the visitors' perception of the room as being large, and its natural size, by describing cities as we currently know them. In the story, these urban features existed only in the past. Ballard's description of the places archived in the microfilms as being "huge" turns out to be an ironic element: 
"“You were lucky to find this place." Rossiter, the most regular visitor, never tired of telling him. He reclined back on the bed, gesturing at the cubicle. "It's enormous, the perspectives really zoom. I'd be surprised if you hadn't got at least five meters here, perhaps even six." Ward shook his head categorically. Rossiter was his closest friend, but the quest for living space had forged powerful reflexes. "Just over four and a half, I've measured it carefully. There's no doubt about it."

Rossiter lifted one eyebrow. "I'm amazed. It must be the ceiling then"' (Ballard, 1962a:10).

The dystopia also describes the historical public spaces as spaces with few people, a scene that is inconceivable to the characters in the story. Ballard also refers to loss of public space in a literal sense. Public spaces were replaced by dwelling spaces, which he calls 'housing batteries'. Since the only building typology was reduced to apartment buildings alone, publicity could only be provided in the staircases used as informal lounges:

'Rossiter grinned. "Of course, John. I'm just envious, that's all. My room's driving me crazy." Like everyone, he used the term 'room' to describe his tiny cubicle, a hangover from the days fifty years earlier when people had indeed lived one to a room, sometimes, unbelievably, one to an apartment or house. The microfilms in the architecture catalogs at the library showed scenes of museums, concert halls, and other public buildings in what appeared to be everyday settings, often virtually empty, two or three people wandering down an enormous gallery or staircase. Traffic moved freely along the center of streets, and in the quieter districts sections of sidewalk would be deserted for fifty yards or more.

Now, of course, the older buildings had been torn down and replaced by housing batteries, or converted into apartment blocks. The great banqueting room in the former City Hall had been split horizontally into four decks, each of these cut up into hundreds of cubicles (Ballard, 1962a:8-9).

In Billennium, the 4-square metered-units of living are shown as dystopias. Also the density in the city-scale is emphasized by the efforts to prevent the invasion of agricultural lands by the suburbs:

'How long it could continue was impossible to estimate. Despite the gloomiest prophecies of the Neo-Malthusians, world agriculture had managed to keep pace with the population growth, although intensive cultivation meant that 95 percent of the population was permanently trapped in vast urban conurbations. The outward growth of cities had at last been checked; in fact, all over the world 
former suburban areas were being reclaimed for agriculture and population additions were confined within the existing urban ghettos. The countryside, as such, no longer existed. Every single square foot of ground sprouted a crop of one type or other. The onetime fields and meadows of the world were now, in effect, factory floors, as highly mechanized and closed to the public as any industrial area. Economic and ideological rivalries had long since faded before one overriding quest-the internal colonization of the city' (Ballard, 1962a:12).

What Ballard describes as the dystopian modernity, with its consequent need urban density had already been expressed by Le Corbusier in 1920s. Le Corbusier describes one of his principles for a sound urban planning as the need to "augment their density" in The City of To-morrow published in 1929. He shows support for density, stating that: 'The more dense the population of a city is, the less are the distances that have to be covered. The moral, therefore, is that we must increase the density of the centers of our cities, where business affairs are carried on' (cited in Fishman, 1977:370). Shortening the distances and creating open spaces forces the city to be vertical in his project. (Allan) Jacobs and Appleyard (1987), in their paper 'Toward an Urban Design Manifesto' define the minimum dwelling density as being one of the five elements for composing a healthy city life and they offer a large number of discrete and independent buildings, as opposed to fewer large-scale buildings. They propose 'a minimum density', because 'cities are more than stage sets, and for the sake of Human exchange, public life and action, diversity and community' (Jacobs and Appleyard, 1987).

'There are five physical characteristics that must be present if there is to be a positive response to the goals and values we believe are central to urban life. They must be designed; they must exist, as prerequisites of a sound urban environment. All five must be present, not just one or two. There are other physical characteristics that are important, but these five are essential: livable streets and neighborhoods; some minimum density of residential development as well as intensity of land use; an integration of activities -living, working, and shopping- in some reasonable proximity to each other. A manmade environment, particularly buildings, that defines public space (as opposed to buildings that, for the most part, sit in space); and many, many separate, distinct buildings with complex arrangements and relationships (as opposed to few, large buildings)' (Jacobs and Appleyard, 1987:443).

Trancik emphasizes that multi-floor buildings affect the scale of the city and therefore their micro-city features cannot be the equivalent of real city life. $\mathrm{He}$ also points out that the order of the buildings should function in the social order as well: 
'Isolated "superblocks" formed by urban renewal plans closed off historic streets, drastically affecting the scale of the city. Abstract notions of compatible uses created urban areas that could no longer accommodate physical or social diversity, and that therefore were no longer truly urban. Both zoning and urban renewal substituted functional for spatial order and failed to recognize the importance of social order to social function' (Trancik, 1986:12).

\section{Conclusion}

Ballard's literature, in which the earth itself is represented as an 'alien' object, provides a fruitful resource for the construction of this study. The concept of urban concentration and the ability of this concept to create a transformation of scale was first proposed in the Concentration City, written in 1957 and reiterated in Billenium and Chronopolis and, 1961 and 1962, respectively. These themes, which appeared early in his work, play an important role in the construction of Ballardian discourse. The long and continuous historical process that includes the discourses of Trancik and Jacobs and Appleyard reveal the importance of the impact of this theme in the architectural realm.

Ballard does not create new realities; rather, he interprets the conditions of the recent past as well as the present into a future perspective, and he establishes his criticism through the overstatement of these conditions through what we call dystopia. In this respect, the premise of the study can be reviewed as follows: the data provided by the fictional representation of space in Ballard's dystopian world can provide new knowledge when conveyed to the epistemological realm of architecture.

\section{Bibliography}

Ballard, J.G. (1971). 'Concentration City.' In Chronopolis and Other Stories, 209231. New York. Berkley Publishing Corp.

Ballard, J.G. (1962a). 'Billenium.' In Billenium, 7-20. New York: Berkley Publishing Corp.

Ballard, J.G. (1962b). 'Chronopolis.' In Billenium, 117-139. New York: Berkley Publishing Corp.

Fishman, R. (1977). Urban Utopias in the Twentieth Century: Ebenezer Howard, Frank Lloyd Wright, and Le Corbusier. New York: Basic Books.

Gasiorek, A. (2005). JG Ballard (Contemporary British Novelists). Manchester and New York: Manchester University Press.

Jacobs, A., Appleyard, D. (1987). 'Toward an Urban Design Manifesto.' Journal of the American Planning Association, 53: 437-447.

Sanna, I. (2013). 'Time and Space in J. G. Ballard's Chronopolis.' Available at: http://www.academia.edu/431599/Time_and_Space_in_J._G._Ballards_Chronop olis [13 May 2013] 
Taylor, J.S. (2002). 'The Subjectivity of the near future: Geographical imaginings in the work of J.G. Ballard.' In: R. Kitchin, J. Kneale (eds.), Lost in Space, London and New York: Continuum.

Thomson, S. (1996). 'Places within and without: memory and literary imagination, and the project in the design studio.' In: Elena Bastea (ed.), Memory and Architecture, 317-330. New Mexico: University of New Mexico Press.

Trancik, R. (1986). Finding Lost Space: Theories of Urban Design. New York: Van Nostrand Reinhold.

Tümer, G. (1997). İnsan-mekan ilişkileri ve Kafka. İzmir: Sanat-Koop Yayınları. 